Wayne State University

DigitalCommons@WayneState

Teacher Education Faculty Publications

Teacher Education

$1-1-2011$

\title{
Landscapes of City and Self: Place and Identity in Urban Young Adult Literature
}

Ebony Elizabeth Thomas

Wayne State University, eethomas@wayne.edu

\section{Recommended Citation}

Thomas, E. E. (2011). Landscapes of city and self: Place and identity in urban young adult literature. The ALAN Review 38(2), 13-22. Available at: http://digitalcommons.wayne.edu/coe_ted/3

This Article is brought to you for free and open access by the Teacher Education at DigitalCommons@WayneState. It has been accepted for inclusion in Teacher Education Faculty Publications by an authorized administrator of DigitalCommons@WayneState. 


\title{
Landscapes of City and Self:
}

\author{
Place and Identity in Urban Young Adult Literature
}

\author{
"Every ghetto, every city, \\ Every suburban place I been \\ Makes me recall my days in the New Jerusalem . . . ." \\ -Lauryn Hill
}

$\mathbf{U}$ rban landscapes feature iconic symbols from the past and contemporary times. These symbols become representative artifacts of their cities, from the Empire State Building in New York City to the Golden Gate Bridge in San Francisco. Physical spaces such as these are emblazoned in the consciousness of city dwellers and visitors all over the United States and around the world. These spaces serve not only as settings and backdrops for memory, but often become metaphors for cities themselves. Just as we notice the beauty of a person's eyes, and remember them clearly many years later, we also notice and remember (and in the case of natives, often take for granted) the distinctive smell of a wharf in Washington, D.C. or Baltimore in the summertime, the colorful jubilation of Jackson Square in New Orleans during Mardi Gras, or the quiet desolation of Michigan Central Station in postindustrial Detroit. We also remember virtual urban landscapes in young adult literature long after we have read the final page, from the delightful renderings of a Chicago Chicano neighborhood in The House on Mango Street (Cisneros, 1991) to a glorious summer at the Philadelphia art school in Same Difference (Vivian, 2009). These noticings and remembrances from life and literature contribute to the formation of readers' identities, as well as their sense of being anchored in worlds both real and fictional.

As the geographic, cultural, and economic distinctions of cities are taken for granted, there are even broader implications for readers, teachers, and critics of adolescent literature. The first is that of relevance. There are relevant connections between literature for young adults and trends in the culture of urban centers. We are living during a time of profound cultural shifts. World populations are more urban than in any other time in human history. Global economies, new technologies, rapid information flow, and transnational workforces are rapidly changing the cities that we live in (Gere, Aull, Dickinson, McBee-Orzulak, \& Thomas, 2007).

To thrive, city dwellers of all ages must constantly shift from one context to the next, often many times within the same day and during moment-to-moment interactions with others. We may now choose from among a myriad of information modes (snail mail, email, text messaging, IM, Facebook, or Twitter), orienting ourselves in texts according to the interpersonal relationships involved (using netspeak with close friends and loved ones, using a more formal register with teachers and supervisors, and adopting an anonymous online persona on MySpace), and 
shattering age-old barriers of space and time (instant access to anyone with an Internet connection, in any time zone, anywhere in the world). In young adult literature, we have seen this trend in recent titles that make extensive use of netspeak, such as ttyl and its sequels (Myracle, 2005), as well as in the proliferation of spaces online where authors of adolescent literature and their fans can connect.

Yet even in the midst of technological innovation, globalization, and urbanization, many still find value in affirming premodern and modern identities and

\section{quote} nature of many of today's communication modes has inspired a return to that which is tangible, local, and immediate-that is, a sense of place. The urban geographies imagined and described in 21st-century fiction for young adults provide orientations and grounding in specific places. These story places are as diverse and interconnected as that of any natural biome.

A focus on urban settings has implications for adolescent literacy development. Educators often ask students to focus on the descriptive language in a novel as part of the meaning-making transaction between author and reader (Rosenblatt, 1983; Wilhelm, 2008). Often, to demonstrate comprehension and to practice describing their own experiences of being in the world, students are asked to compose original texts in response to their reading. Depending upon a teenager's previous urban experiences, the imagined city in Lyra's Oxford (Pullman, 2003) or the dystopian San Francisco in Doctorow's Little Brother (2008) may be as new and strange as the Philadelphia of Flake's novels (i.e., The Skin I'm In [2000], Who Am I Without Him? [2004], and Bang! [2005]) are familiar to others. Reading about different kinds of places may change students' previously held views about cities, or in the case of city dwellers, affirm their sense of identity and belonging. As they are transported into these urban spaces through literature, young adults expand their view of the world and what it means to be a citizen in it.

If urban geographies provide unique experiences for students' entertainment and their literacy learning, it is also important to note that not all city landscapes are created equally. Just as cities themselves are stratified by socioeconomic status, culture, race, religion, orientation, and immigrant status, today's adolescent literature features urban geographies of both privilege and challenge, as well as contact zones where the two landscapes meet. From Gossip Girl (von Ziegesar, 2002) to Hip-Hop High School (Sitomer, 2006), these novels are some of the most popular in the field. Yet reading such texts for the role of place and environment is often subordinated by other concerns, such as a focus on identity, ideology, or culture (Glenn, 2008).

In this article, I read across recent urban YAL offerings for landscapes of privilege and challenge, as well as spaces where different zones intersect. As my analysis is focused on place, I use theories of cosmopolitanism to examine socioeconomically privileged spaces in the Gossip Girl and Princess Diaries (Cabot, 2000) series, as well as the ways in which this privilege is contested in Little Brother (Doctorow, 2008) and The Earth, My Butt, and Other Big Round Things (Mackler, 2003). Moving on to urban landscapes of challenge, I examine descriptions of the specific physical constraints of ghettos and barrios in the work of de la Peña, Mowry, and Booth, among others, as well as some of the distinctive, treasured landmarks of these communities, realized in Flake's You Don't Even Know Me (2010) and Myers's What They Found: Love on 145th Street (1999b). Finally, I examine a few of the books where privilege and challenge intersect in varying ways. I conclude by proposing some practical applications of the study of urban geographies in young adult literature for teaching, learning, and activism. 


\section{Urban Geographies of Privilege}

Twenty-first century urban geographies of privilege have been exacerbated by globalization and cosmopolitanism. The notion of cosmopolitanism can be traced back to the Cynics and the Stoics of Hellenistic Greece, who coined this paradoxical term to refer to a "citizen of the cosmos" (Appiah, 2006) that belongs to all communities and none at the same time. Yet the ability to become a cosmopolite is necessarily circumscribed by socioeconomic factors. "Transnational elites exist in positions of power and privilege enabling them to act as cosmopolites" (Binnie, Holloway, Millington, \& Young, 2006), although the experiences of the global urban elite cannot be easily reduced or homogenized. Some urban landscapes of privilege encourage the "voyeuristic desires of readers" (Glenn, 2008), while others actively challenge and even negatively evaluate the lifestyles and values of the wealthy and powerful.

Stories about privileged urban adolescents are often (yet not exclusively) set in New York City. Two of the most popular series that recount teens living in these landscapes of wealth have been serialized, imitated, and found homes in movie theaters, on television sets, and on DVD. Perhaps the most quintessential (and stereotypical) depiction of the New York upper class can be found in the Gossip Girl novels, where Blair Waldorf, Serena Von Der Woodsen, and friends indulge in sex, lies, and character assassination on the Upper East Side (von Ziegesar, 2002a). Material wealth and desirable real estate, schools, retail choices, and vacation spots are central to the series. As the Gossip Girl blog recounts in the second novel, You Know You Love Me (von Ziegesar, 2002a), "Winter is coming. It's the city's favorite season and mine, too .... it's time to break out those credit cards and hit Bendel's and Barney's for some cool new boots, sexy fishnet tights, little wool skirts, and delicious cashmere sweaters. The city feels a little sparklier this time of year, and we want to sparkle with it!" (p. 1). Throughout the series, the descriptions of Park Avenue, exclusive Upper East Side real estate, and exclusive shopping venues are described as enthusiastically as the infidelity and rumor mongering in which Blair and friends frequently indulge. The Gossip Girl novels describe a cosmopolitan world, but not a very nice one.

In contrast, The Princess Diaries (Cabot, 2000) features an upper middle class teen, Mia Thermopolis, who is far less reptilian than the Gossip Girl characters. Yet even before she learns that she is royalty, Mia's landscapes of privilege are just as apparent as those in the aforementioned series. While Mia's hometown in the Disney movies is San Francisco, in the novels she attends a Manhattan private school and lives in "a bohemian artist's loft in Greenwich Village." As endearing as Mia's penchant for awkward situations and clumsiness might be, even before she learns that she is a princess, she is a transnational cosmopolite, spending summers with her wealthy father and grandmere in the fictional nation of Genovia.

Once Mia learns that she is heir to the throne, she processes the information inside of a women's powder room in the Plaza Hotel. Mia breaks the fourth wall and shares in a breathless aside, "I don't know if you've ever been to the ladies' room at the Plaza, but it's like totally the nicest one in Manhattan. It's all pink, and there are mirrors and little couches everywhere, in case you look at yourself and feel the urge to faint from your beauty or something .... I went into one of the stalls, each of which, besides a toilet, has its own private sink with a huge dressing table with a little stool with tassels hanging off it" (pp. 38-39). Clearly, Mia is familiar with a number of settings that are fit for a crown princess even before she learns of her royal status. Her launch into the cosmopolitan status of a monarch is rocky, but does not require an unbelievable stretch of the imagination. One may speculate on the reasons why Mia's privilege prior to becoming a princess is downplayed in the Disney movie-other than attending private school, she is portrayed as a middle class teenaged girl. Perhaps those responsible for translating her character from page to screen believed that adolescent girls from all socioeconomic classes might be more sympathetic toward a character that could relate to their experiences.

Not all teen characters inhabit privileged urban space uncritically. In Little Brother, (Doctorow, 2008) Marcus is the leader of a group of teen hackers who chafe against the restrictions of their surveilled environment in a San Francisco of the near future, and then are caught up in the nation's most devastating terrorist attack since 9/11. Marcus lives with his parents in a gentrified older neighborhood in the city, Potrero Hill: "It's all residential streets, and the old Victorian houses they call 'painted ladies' for their 
gaudy, elaborate paint jobs, and front gardens with scented flowers and tall grasses. Housecats stare at you from hedges, and there are hardly any homeless" (2008, p. 75). At the end of the first decade of the 21st century, the average listing price for real estate in Potrero Hill was $\$ \mathbf{7 6 6 , 4 3 4}$ (trulia.com), while the median national price for a single family home is only $\$ 183,100$. Unlike the characters in other geographies of privilege, Marcus sees the living conditions of challenge. He contrasts his neighborhood with a poorer one, the Mission: "Lots of rowdy drunks and angry crackheads and unconscious junkies, and also lots of families with strollers, old ladies gossiping on stoops, lowriders with boom-cares going thumpa-thumpa-thumpa down the streets . . . . also drag queens, angry gang kids, graffiti artists and bewildered gentrifiers trying not to get killed while their real estate investments matured" (pp. 70-71). Marcus is self-aware of the class differences in his city, but his notoriety on the Internet imbues him with a cosmopolitan status that would not be possible without access to the latest technology, accessories, and equipment.

The Earth, My Butt, and Other Big Round Things (Mackler, 2003) offers another critique of urban upper class landscapes. Virginia is the plus-sized daughter of a psychologist specializing in adolescents. She is obsessed with being thin, especially in light of her two naturally svelte older siblings. Her brother, Byron, is a sophomore at Columbia University. To Virginia, his surroundings seem to serve as a metaphor for his good looks and apparent charm: "As I step through Columbia's entryway, all the buildings look identical-stately, stone, draped in ivy . . . it's a balmy fall afternoon, so the grassy expanses in front of the majestic library are overflowing with students" ( $p$. 48). Later in the story, when she rebels against her parents' ostracism because of her weight and visits her best friend in the Pacific Northwest, Virginia finds an urban landscape where she feels at home: "As I gaped at Mount Rainier, I was both speechless and elated. That's how I've been since I arrived in Seattle. Not speechless as much as elated. For the first time in months, I've been laughing at even the silliest things . . .” (p. 172). Her relationship with food even changes as she reflects on the geographies of social privilege in both cities: “The strangest thing is that I'm not thinking about food all the time. Rather than constantly munching, like I do at home, I'm just eating when I'm hungry" (p. 172). For Virginia, upper crust New York is a place where she must eat to cope with her sadness; in Seattle, however, she can fill the void with social interaction. She takes what she has learned about herself through the Seattle trip back to the Big Apple, and is empowered.

Traditionally, novels set in upper middle class and elite settings in the city have not been classified or categorized as urban. Yet as gentrification and the new urbanism become reality in many of our cities, it is important to rethink mid-20th-century conceptions of city spaces, which were more appropriate for a time when suburban car culture was in its infancy and cities were in decline (Sandercock, 2003). Today, "contemporary cities are sites of struggles over space, which are really two kinds of struggle: one a struggle of life space against economic space, the other a struggle over belonging” (p. 4). Sandercock also suggests that in cities, often the role of planning "has been to regulate the production and the use of space .... planners have acted as spatial police ... regulating bodies in space, administering who can do what and be where, and even when" (p. 21). This regulation of the body has some implications for upper middle class and wealthy teen characters, but it also defines the urban landscape for their less-privileged counterparts. In contrast to the privilege found in some communities of 21st-century cities is a geographic landscape of challenge that can be found in others. In the next section, we travel from mansions and penthouses to the ghettos and barrios that are often located within the same city, and examine urban geographies of challenge.

\section{Urban Geographies of Challenge}

The modern young adult novel has prominent roots in urban settings, from The Outsiders (Hinton, 1967) to The Pigman (Zindel, 1968). While the landscape of urban privilege in most contemporary adolescent literature is taken for granted or, as in the preceding 
novels, depicted as desirable, the geographic challenges of urban life are foregrounded through descriptions of unsafe streets and schools and perilous home environments. The language used to describe these environments is that of decay and the criminal justice system-crumbling streets, sirens, gunshots, and suffocating restrictions on physical movement. When characters do venture outside of the ghetto, the barrio, or the trailer park, they are faced with the realities of racism and class privilege. This type of landscape is what urban has come to mean in our popular consciousness.

Some of these stories serve as a general commentary about inequities in our society. Coe Booth's work with youth in the New York City Children's Emergency Service inspired the character of Tyrell (in Tyrell, Booth, 2006), a 15-year-old under duress (Blasingame, 2007). Others serve as treatises about the young people whose lives are most imperiled. The protagonist in Monster (Myers, 1999a) dreams of being a filmmaker, yet is on trial as an accomplice to murder. Through his film script, the reader is able to visualize the Manhattan Detention Center: "The best time to cry is at night, when the lights are out and someone else is being beaten up and screaming for help. . . . There is a mirror over the steel sink in my cell. It's six inches high, and scratched with the names of some guys who were here before me” (p. 1). In Bang! (Flake, 2005), 13-year-old Mann begins his Philadelphia story with “They kill people where I live. They shoot 'em dead for no reason. You don't duck, you die” (p. 1). The realistic urban geography of challenge faced by the characters in Tyrell, Monster, and Bang! stands in stark contrast to the more privileged locales and lives in the city. The cosmopolitan teens of the upper class urban elite travel to locales all over the world, whether real or virtual. In contrast, the worlds of the lower middle class, working class, and impoverished teens navigating challenging landscapes are much more localized and immediate.

Dreaming of better circumstances against all odds is a feature of the urban geography of challenge. In After Tupac and D Foster (Woodson, 2008), D serves as a female doppelganger for the soon-to-be-fallen rap star Tupac Shakur: "D started singing real soft 'Dear Mama,' the Tupac song where he talked about having a beef with his mom but loving her anyway . . . we got quiet. An ambulance raced by, and way down the avenue, somebody started honking their car horn like they didn't have any sense” (p. 19). The First Part Last (Johnson, 2004) offers hope through the story of a young teenaged father's love for his baby daughter and the neighborhood that cradles them both: "I used to laugh when this old dude, 'Just Frank' from the corner, used to ask me

\section{quote} if I was being a 'man' . . . two days after I brought Feather home, Frank got killed trying to save a girl in the neighborhood from being dragged into an alley by some nut job. Didn't have any family. Didn't have any money. So the block got together to pay for his funeral ...” (p. 7). In the midst of extremely difficult circumstances, city dwellers constrained by landscapes of challenge display audacious hope, tenacity, and love.

Other characters struggle with whether or not to escape the geography of challenge altogether for more privileged zones. Way Past Cool (Mowry, 1992/2007), set in Oakland, California, is the story of the Friends, a skateboarding clique that struggles to hold down their block against the onslaught of rival drug-dealing gangs. Their neighborhood is realized in richly descriptive passages: "Back at the other end of the alley, the boys picked up their school things, shouldered packs, and decked their boards, and the faint jingle of a burglar alarm bell carried from blocks away. The Friends skated casually, weaving around people, dodging the legs of wineheads and zoners sticking from doorways ...” (p. 56). In this milieu, success is defined and narrated as escaping the ghetto altogether, creating dilemmatic tension for the Friends. Similarly, Mexican WhiteBoy (de la Peña, 2008) deals with the challenges of biracial identity in the barrio. As Uno considers whether to move to Oxnard with his African American father or remain with his Mexican mother, National City is described: “Uno's stuck in the middle . . . like it's some tug-of-war between black and Mexican, and he's the rope ... he cuts into the mouth of Las Palmas Park, slides down the ice-plantcovered hill, races along the weed-infested baseball 
field, and leaps the crumbling fence along the firstbase line. He ducks under the rusted bleachers, chest heaving in and out, heart pounding in his throat" ( $\mathrm{p}$. 38). Struggling with his dilemma, it is interesting to note that Uno enters the virtual prison of the rusty bleachers, restricting his own physical movement for hours as he considers his choices.

\section{quote}

main character in Johnson's Suite Scarlett (2008) has to clean hotel rooms for a living. Almost Home (Blank, 2007) and Absolutely Maybe (Yee, 2009) feature white teens who run away to Hollywood in search of fame and fortune. The Hoopster (Sitomer, 2005) and Black or White (Volponi, 2005) feature urban interracial clashes that ultimately end in disaster.

In order to tell 21st-century urban tales, stories of privilege and challenge are necessary. The geography of privilege features symbolic places that bring to mind princesses, nobility, incredible wealth, even (in the case of the Gossip Girl series) greed, excess, and overindulgence. The geography of challenge, on the other hand, highlights people and places that bring to mind social justice, altruism, social change, and knowledge about not only what we might do for the least of these, but also the power of the least of these. For many readers of urban fiction, and their teachers, the challenging landscapes of the 'hood are beloved. In What They Found: Love on 145th Street (Myers, 1999b), everyone is interconnected, from the crossing guards to store owners: "The bodega on 138th Street is always the first store open that takes our card. Mr. Alvarez always says he shouldn't let me use it, but he always does ...” (Myers, 1999b, p. 31). Along with the possibility of thriving in these spaces through strategies of mutual interdependence, there are moments of tranquility and harmony that the barrio and the ghetto provide to poor and working class city dwellers. The sentiment of the opening quote is echoed by one of the Philadelphia boys in You Don't Even Know Me (Flake, 2010). "I watch my neighbors kicking back, talking on cells and to each other. I hear Miss Bert yelling to someone to bring her a bowl of butter pecan ice cream, and some grease so she can oil her scalp” (p. 166). He goes on to reflect on how much he appreciates where he lives: "Philly heat. It makes people stay outdoors all night long . . . that's why I like it though . . . knowing that it ain't all bad; ain't all good, neither. It's just where I live. My hood" (p. 167).

\section{Intersecting Trajectories in the City: Where Privilege Meets Challenge}

As we consider urban settings, Pratt suggests that a contact zone is "the spatial and temporal copresence of subjects previously separated by geographic and historic disjunctures, whose trajectories now intersect" (Pratt, 1992). Intersecting trajectories that blend urban landscapes of privilege and challenge are prevalent in recent young adult literature. Even though urban spaces are often carefully planned and/or policed to keep the privileged and the challenged separate, coevalness or "the sharing of the present time" is a fundamental condition for social change and social justice (Duncan, 2006). It is inevitable that the trajectories of those who live in various urban spaces will intersect, for better or for worse. Additionally, the notion of who is urban, what locations in urban space are like, and how place is represented is central in many young adult texts.

Twenty-first century Romeo and Juliets abound, from Romiette and Julio (Draper, 1999), to Othello (Lester, 1998), to Son of the Mob (Korman, 2004). Woodson's If You Come Softly (1998) is the story of Ellie, who is white, and Jeremiah, who is black. Their story captures the wonders of first love and the agony of the tragedy caused by their intersecting trajectories in Washington Heights. On a lighter note, Cohn and Levithan's Nick and Norah's Infinite Playlist (2006) features the star-crossed pairing of Nick, who is from Hoboken and the straight bassist in a queercore band, and Norah, a Jewish girl who attends a Catholic school. Norah's noticings in the beginning 
are less than flattering toward Nick: "NoMo dresses so bad-he has to be from Jersey . . . the van's probably a piece of scrap metal with a leaking carburetor that as likely as not will pop a tire or run out of gas in the middle of the Lincoln Tunnel ...” (p. 10). Although the course of true love never did run smoothly, Nick and Norah manage a happy ending at the end of their hilariously profane romp through New York City.

A growing number of young adult authors situate characters of color in middle class and elite settings. In A La Carte (Davis, 2008), Lainey is a San Francisco vegan who dreams of being the African American answer to Julia Child. She creates magnificent recipes in a tattered notebook and works part-time at her single mom's fusion restaurant: "The noise this afternoon isn't as urgent yet as it is during dinner service. So far it's laughter, conversation, the rhythmic thunk, thunk, thunk of heavy knives slicing through vegetables and bone to make stock for the gravies and sauces . . . the back door opens” (p. 26). The sights and sounds of this black urban teen's lifeworld are very different from those found in city landscapes of challenge. Marcelo in the Real World (Stork, 2009) is the lyrical story of a mildly autistic Latino teen who is the son of a Boston attorney. Through working in his father's law firm over the summer, Marcelo experiences life beyond the protective environments of his home and school. "We are walking on the sidewalks next to streets clogged with cars. The sidewalks themselves are difficult to walk because of the number of people rushing to catch trains and buses, I suppose, or just to get away from their jobs as fast as they can. But as we move from the center of town, there is more room and I can walk next to Jasmine without having to dodge rushing people” (p. 110). Jasmine is the key that unlocks Boston for Marcelo, inspiring him as he gains the confidence to enroll in a comprehensive high school.

The tragedy of September 11, 2001, formed another convergence where geographies of privilege and challenge intersected. Extremely Loud and Incredibly Close (Foer, 2005) is the story of wunderkind Oskar, whose father perished in the Twin Towers. His detective work takes him all over the five boroughs of New York City, where he meets people from all walks of life who were profoundly affected by the incident. Throughout Foer's novel, visual depictions of the tragedy and even the ways that words are spaced on each page form an internal urban geography designed to evoke a tragic time. Love Is the Higher Law (Levithan, 2009) includes the first-person stories of three teens on the morning of $9 / 11$, positioned and impacted differently. Set two years after the events of 9/11, Someday This Pain Will Be Useful to You (Cameron, 2007) is a Catcher in the Rye (Salinger, 1951) for the new millennium, where cynical protagonist James questions everything-materialism, sexuality, and urban life. As James observes, "The majority of the world's conflicts are caused by religious intolerance. I could go on and on with this, especially with things like 9/11, but I won't”' (p. 41).

Intersecting trajectories create cities of our dreams and nightmares. The Dead and the Gone (Pfeffer, 2008) is the sequel to a novel that speculated on what might happen if our moon's trajectory was knocked closer to Earth. While the first tale was set in exurbia, in The Dead and the Gone, Alex Morales must navigate the landscape of postapocalyptic New York through his resourcefulness, connections to the city's elite, and faith in God. Alex's city landscape becomes perilous during a winter storm: "It took an hour just to get to Seventieth Street, and by then Bri was having difficulty breathing. Julie fell on Sixty-eighth Street, and [he] had to pull her up, which took more energy than he cared to spare at that point. Some of the snow got into Julie's boots, and she began shivering uncontrollably" (p. 263). The urban landscape in The Hunger Games (Collins, 2008) is even more bleak; in this dystopian successor to the United States, the Capitol is the rich metropole where children from the impoverished peripheral districts go to die in a gladiatorial contest. District 12 tribute Katniss Everdeen notes, "My quarters are larger than our entire house back home. They are plush, like the train car, but also have so many automatic gadgets that I'm sure I won't have time to press all the buttons. The shower alone has a panel with more than a hundred options you can choose ..." (p. 75). The descriptions of the luxury 
and indolence of the Capital are starkly contrasted to the near-starvation that District residents must endure. Yet not all imagined cities are nightmarish. Lyra's Oxford (Pullman, 2003) is delightfully whimsical, and the accessible Bluford High (Langan, 2006) series features positive characters from tough backgrounds.

This reading of city landscapes in young adult novels is not meant to be comprehensive or exhaus-

tive, but to provide insight into looking at privilege, challenge, and the contact zones where the two geographies intersect as a method of highlighting urban issues that future generations will have to consider within the context of their 21st-century world. Discourses of cosmopolitanism, gentrification, increased attention to the local, and managing

conflict and tension within contact zones dominate national and global politics as well as media headlines. At a time when our natural resources are being depleted, our energy sources are becoming strained to the breaking point, and there is a dearth of unfiltered information about the challenges that even the most privileged of our teens will face in their lifetimes, texts that present urban geographies provide an opportunity for young readers and the stakeholders in their lives to consider the present and future states of our cities wherein the privileged and the challenged meet.

\section{Learning More about Urban Landscapes in Literature and Life}

Examining urban landscapes has practical applications for teaching, learning, and activism. A popular activity used in multicultural education and diversity training is the privilege walk, during which a series of statements are read, and participants must move backwards or forwards according to whether it applies or not. Previously, a colleague and I described our use of the privilege walk with a challenging ninth-grade class:

In this activity, space is used to visually represent the racial, gender, sexual, and socioeconomic differences among the students in the class. The objective of the privilege walk is to help students understand the nature of privilege (in society). Students line up across the middle of the room, the facilitator reads a series of statements, and students take steps forward or backward depending on whether the statement applies to them.

Sample statements include, "If you were ever discouraged from academics or jobs because of race, class, ethnicity, gender or sexual orientation, take one step back" and "If your family ever inherited money or property, take one step forward" (Sassi \& Thomas, 2008).

At the end of the activity, the most privileged participants are standing near the front of the space, while the least privileged are near the back. This provides a visual landscape representing the persistence of inequities in our schools and society. Participants often report that the privilege walk is transformative for them and aids their understanding of issues of social justice (Cooper, 2007; Sassi \& Thomas, 2008).

A useful extension after reading a young adult novel set in urban spaces would be to conduct a challenge walk. This is an activity that I often facilitated in my Creative Writing and Magazine classes in an urban magnet high school. First, I secured permission from building administrators and/or parents, depending upon the age range of the students involved. Then I did a bit of informal pre-teaching about participant-observation methods and strategies. I did not prescribe what students ought to take away from the experience of walking the neighborhood nearest the school, nor did I provide a set of questions. Instead, I talked about the best ways to capture details, and brainstormed with the students about how to proceed. Next, students were equipped with disposable cameras and small notebooks. Finally, we mapped out our route and started walking.

Once we returned, the students and I processed what we saw. They chose to journal about their experiences, write poetry, and conduct investigative journalism about unsafe conditions. Now that I am a teacher educator, I ask my university preservice and inservice teachers to write and draw a conceptual map of local challenge and privilege. When I talk to my preservice teachers about this activity, I suggest that they use the Beginner's Guide to Community-Based Arts (Schwarzman \& Knight, 2006), Ethnographic Eyes (Frank, 1999), and even the delightful My Map Book (Fanelli, 1995) if they are planning to guide students through analyses of their own neighborhoods and 
communities. (Students could also use one of the young adult novels discussed above to make their conceptual maps.) Young adults are asked to first think, then write, using the following series of prompts:

- What challenges are unique to our neighborhood? Where is privilege located? Where and how do privilege and challenge intersect?

- Which areas are unique? Which might interest a newcomer? Which are most beloved and sacred to us?

- What resources are here? What is being overlooked? What is being exploited and overused? What is being treasured?

- What might we wish to preserve? What might we wish to change?

Another related project that can be done with secondary English language arts students is a literary social analysis. Students first read a young adult novel of their choosing, or an adult novel that features teen characters. Selection guidelines for the project are: 1) the book has to have an urban setting, and 2) a parent or guardian has to sign a permission slip acknowledging that they are aware of what their teen is reading. Students then identify a primary social challenge that their characters face, or that is inherent in the setting. Using school and district libraries, they find three or more nonfiction articles that deal with the topic-teen pregnancy, HIV/AIDS, urban violence, mental health, etc. They present summaries and analyses of their research to the class. These drafts eventually become a position paper. During the next two weeks, students read their high-interest urban novels, summarize them, and then use their position paper as a secondary source to write an analysis. Students then present and publish their finished papers as a capstone project for the benefit of the class and community.

At the dawn of a new century, it is as vital for urban dwellers to recognize hope and possibility in the city as it is for suburban and rural kids to view cities as opportunities for new visions of empathy for others, virtual experiences, and cross-cultural understanding. Urban adolescent literature has the potential to encourage all of us to recognize and critically interpret the real conditions of our existence. Authors of today's fiction for young adults are on the vanguard of new ways of visualizing urban spaces. Those of us living at the intersections of these trajectories-teach- ers, librarians, students, and activists-are similarly positioned to build the cities of our dreams.

Author's Note: I am indebted to the following ALAN colleagues and contributors to the Child_Lit listserv, Rutgers University, for their initial book suggestions during the preparation of this article: Thom Barthelmess, Jennifer Buehler, Ariel Zeitlin Cooke, Gail de Vos, Rachel DuBois, Susan Ellman, Megan Isaac, Brenda Kahn, Cheryl Klein, Carolynne Lathrop, Nina Lindsay, Beth Medley, Lyn Miller-Lachmann, Kerry Mockler, Rosanna Perry, Judith Ridge, Maureen Picard Robins, Vicky Smith, Ed Spicer, and Alison Waller.

Ebony Elizabeth Thomas is an assistant professor of Reading, Language, and Literature Education at Wayne State University. A former Detroit Public Schools teacher, her research interests include adolescent literatures and literacies, discourse analysis, and English language arts classroom interaction. She may be reached at eethomas@ wayne.edu.

\section{References}

Appiah, K. A. (2006). Cosmopolitanism: Ethics in a world of strangers. New York and London: W. W. Norton.

Binnie, J., Holloway, J., Millington, S., \& Young, C. (2006). Introduction: Grounding cosmopolitan urbanism: Approaches, practices, and policies. In J. Binnie, J. Holloway, S. Millington \& C. Young (Eds.), Cosmopolitan urbanism (pp. 1-34). London and New York: Routledge.

Blank, J. (2007). Almost home. New York: Hyperion.

Blasingame, J. (2007). "What a Man Do": Coe Booth and the genesis of Tyrell. ALAN Review, 34(2), 28-33.

Booth, C. (2006). Tyrell. New York: Scholastic.

Cabot, M. (2000). The princess diaries. New York: HarperTeen. Cameron, P. (2007). Someday this pain will be useful to you. New York: Picador.

Cisneros, S. (1991). The house on Mango Street. New York: Vintage Contemporaries.

Cohn, R., \& Levithan, D. (2006). Nick and Norah's infinite playlist. New York: Knopf Books for Young Readers.

Collins, S. (2008). The hunger games. New York: Scholastic.

Cooper, J. E. (2007). Strengthening the case for communitybased learning in teacher education. Journal of Teacher Education, 58, 248-255.

Davis, T. (2008). A la carte. New York: Knopf Books for Young Readers.

de la Peña, M. (2008). Mexican whiteboy. New York: Delacorte Books for Young Readers.

Doctorow, C. (2008). Little brother. New York: TOR.

Draper, S. (1999). Romiette and Julio. New York: Simon and Schuster.

Duncan, G. A. (2006). Critical race ethnography in education: 
Narrative, inequality, and the problem of epistemology. In A. D. Dixson \& C. K. Rousseau (Eds.), Critical race theory in education: All God's children got a song (pp. 191-212. New York and London: Routledge.

Fanelli, S. (1995). My map book. New York: HarperFestival.

Flake, S. (2005). Bang! New York: Hyperion.

Flake, S. (2000). The skin I'm in. New York: Hyperion.

Flake, S. (2010). You don't even know me: Stories and poems about boys. New York: Jump at the Sun.

Flake, S. (2004). Who am I without him? New York: Hyperion.

Foer, J. S. (2005). Extremely loud and incredibly close. New York: Mariner Houghton Mifflin.

Frank, C. (1999). Ethnographic eyes: A teacher's guide to classroom observation. Portsmouth, NH: Heinemann.

Gee, J. P. (2003). What video games have to teach us about literacy and learning. Hampshire, UK: Palgrave Macmillan.

Gere, A. R., Aull, L., Dickinson, H., McBee-Orzulak, M., \& Thomas, E. E. (2007). 21 st century literacies: A policy brief produced by the National Council of Teachers of English. NCTE Council Chronicle, 17(2), 13-20.

Glenn, W. (2008). Gossiping girls, insider boys, A-list achievement: Examining and exposing young adult novels consumed by conspicuous consumption. Journal of Adolescent and Adult Literacy, 52, 34-42.

Hinton, S. E. (1967). The outsiders. New York: Viking.

Johnson, A. (2004). The first part last. New York: Simon Pulse. Johnson, M. (2008). Suite Scarlett. New York: Point.

Jones, P. (2008). Chasing tail lights. New York: Walker Books for Young Readers.

Korman, G. (2004). Son of the mob. New York: Hyperion.

Langan, P. (2006). The fallen. West Berlin, NJ: Townsend Press.

Lester, J. (1998). Othello. New York: Scholastic.

Levithan, D. (2009). Love is the higher law. New York: Knopf Books for Young Readers.

Mackler, C. (2003). The earth, my butt, and other big round things. Cambridge, MA: Candlewick Press.

Mowry, J. (1992/2007). Way past cool. New York: Farrar, Straus and Giroux.
Myers, W. D. (1999a). Monster. New York: HarperCollins. Myers, W. D. (1999b). What they found: Love on 145th street. Myracle,Pfeffer, S. B. (2008). The dead and the gone. Orlando: Harcourt.

Pratt, M. L. (1992). Imperial eyes: Travel writing and transculturation. London: Routledge.

Pullman, P. (2003). Lyra's Oxford. New York: Alfred A. Knopf Books for Young Readers.

Rosenblatt, L. (1983). Literature as exploration. New York: Modern Language Association.

Salinger, J. D. (1951). The catcher in the rye. Boston: Little, Brown.

Sandercock, L. (2003). Cosmopolis II: Mongrel cities of the 21st century. London and New York: Continuum.

Sassi, K., \& Thomas, E. E. (2008). Walking the talk: Examining privilege and race in a ninth-grade classroom. English Journal, 97(6), 25-31.

Schwarzman, M., \& Knight, K. (2006). Beginner's guide to community-based arts. Oakland, CA: New Village Press.

Sitomer, A. L. (2005). The hoopster. New York: Hyperion.

Sitomer, A. L. (2006). Hip-hop high school. New York: Hyperion Books for Children.

Stork, F. X. (2009). Marcelo in the real world. New York: Arthur A. Levine.

von Ziegesar, C. (2002a). Gossip Girl. New York: 17th Street Productions and Alloy.

von Ziegesar, C. (2002b). You know you love me: A Gossip Girl novel. Boston: Little, Brown.

Vivian, S. (2009). Same difference. New York: Push Scholastic. Volponi, P. (2005). Black or white. New York: Viking Penguin.

Wilhelm, J. D. (2008). You gotta be the book!: Teaching engaged and reflective reading with adolescents. New York: Teachers College Press and NCTE.

Woodson, J. (2008). After Tupac and D Foster. New York: Putnam.

Woodson, J. (1998). If you come softly. New York: Putnam. Yee, L. (2009). Absolutely maybe. New York: Arthur A. Levine. Zindel, P. (1968). The pigman. New York: Harper Trophy. 